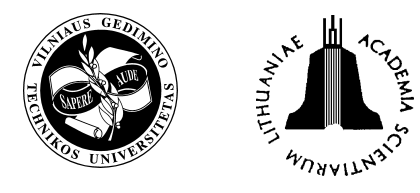

\title{
MANAGERIAL AND ECONOMIC OPTIMISATIONS FOR PREFABRICATED BUILDING SYSTEMS
}

\author{
Ahmed Abdallah \\ Dissertation Supervisor for British Columbia Institute of Technology (BCIT) \\ Canada, Construction Management Program in conjunction with the University of Bath, UK \\ Correspondence: Dr Ahmed ABDALLAH, PhD. \\ Phone: ++-519-4385526 \\ 904 - 390 Burwell St. London Ontario N6B 0A1 Canada \\ E-mail:Dr_ahmedabdelhamid@yahoo.com
}

Received 5 October 2006; accepted 15 February 2007

\begin{abstract}
This paper deals with new realisations of research, scientific development, managerial and economic optimisations - a prefabricated building systems. In the literature, all scientific fields are worked out based on efficiencies, costs, benefits, choice of execution design, technical demands, aesthetical point of view, as well as the total economics. In the present example of a school building for communities in developing countries, the following criteria have been regarded: the optimal superstructure of prefabricated concrete building systems; the particularity of developing countries (eg the climate, the political and economic conditions); the time for construction and necessary innovative developments for an economically optimised superstructure. In addition, alternative construction methods and costs for a simple but variable system which can be adapted to changing functions are suggested.
\end{abstract}

Keywords: construction management, economics, prefabricated systems, managerial and economic optimisations.

\section{Introduction}

The advantage of using prefabricated concrete systems in industrial building is derived from a piece-by-piece model approach, wherein standardisation plays a significant role in achieving economies of scope from the many variations allowed. The choice of light steel framing for the prefabrication base comes from the primary requirement to use automation tools both in the factory and on site. This demands assured dimensional precision and avoidance of problems such as warping and shrinkage. This is a specific implementation of prefabrication; the distinction being that the structures follow an assembly, disassembly, parts replacement, re-assembly sequence as required during their lifecycle. Normal prefabricated structures, however, can only be taken apart with the loss of functionality, either due to unavoidable damage or irreversible jointing. Examining the engineering issues involved taking these principles forward to a true factory-oriented construction scenario using the principles of mass-customisation. This agile production approach involves the design and manufacture of com- ponents and sub-assemblies matched to individual customer requirements. It significantly involves the transport logistics, so that delivery of components is matched to the site automation processes and their sequencing. The future construction systems using prefabricated piece-by-piece methods are expected to bring the following benefits for industry:

1. Advances in the ability of the construction industry to deliver structures at a lower cost with a real improvement in quality over the life cycle.

2. Improved maintainability of the completed product by a more exacting manufacturing process in which the present needs can be balanced with those of a longer term.

\section{Optimisation of prefabricated construction}

Prefabricated construction can be cost-effective both on a first cost and on life-cycle cost projections. Fast construction means earlier occupancy and reduced financing costs. Winter construction can proceed with few weather delays 
as prefabricated components are prefabricated in heated plants. Prefabricated prestressed concrete offers long spans, heavy load-carrying capacity and shallow construction depths. Prefabricated concrete offers corrosion resistance, clean dust-free surfaces, low maintenance and fire resistance. The appearance and aesthetic possibilities of prefabricated offer plenty of design freedom. The prefabricated concrete building systems discussed incorporate the parts necessary for completing a prepared for occupancy building: structural elements, concluding, and building services. The individual building components are industrially made and then assembled on the construction site on the basis of a three-dimensional modular system of ordering the prefabricated components. The size and number of the elements determine the degree of variability, in indirect proportion to costs. Optimisation is necessary that industrial prefabrication must be optimised. In order the costs to be competitive the degree of prefabrication must be increased.

Economical production is possible only in the context of well-defined processes. Another point in support of this is that one is not dependent upon weather conditions or organisational factors on the construction site. Production processes and technologies for building components must be improved. For example, one could integrate different ways of building or one could use prefabricated building component systems on the construction site economically. It is a simple fact that a higher degree of prefabrication requires more work on the part of planners which means that more time must be invested in planning processes. A more accurate planning work could lead to a better efficiency in prefabrication. In the future, industrial prefabrication must face the challenges of accepting individuality as a quality indicator and taking into account the users' needs and wishes. The degree of prefabrication must be individually decided upon and not follow the lines of inflexible modules. Building systems must accommodate individuality not in terms of any one (type of) individual but in terms of a variety of users' interests, because only such flexibility can ensure stability in building value. The interchangeability of components in systems that can later be modernised allows for flexibility of use. One of the most important arguments for prefabrication, which cannot be ignored, is that prefabricated products can deliver high standards of quality. This aspect should be emphasised in setting goals and in argumentation for supporting prefabrication. The experts believe that there exists a great environmental potential in prefabrication because of the possibilities for rational planning and for improved retrofitting and flexibility. Another point in support of this argument is that the materials and process of component prefabrication can be protected from weather conditions. Environmentalism and economy correlate. This means that through prefabrication improved environmental efficiency can become standard.

\subsection{Ecological concerns}

The construction sector plays a significant role in economic development in every country. It provides the direct means to the development and expansion of economic activities as well as being a major consumer of physical, natural resources, and a polluter of the environment. Over the last 30 years, the environmental impact of human settlement development, including construction activities, has grown dramatically due to the sheer increase of the world population and greater industrial and human activities. There are numerous environmental impacts of construction activities. Building construction accounts for $25 \%$ of the forest wood and $40 \%$ of the raw stone, gravel and sand used in the world each year. Globally, buildings consume $16 \%$ of the world's fresh water and $40 \%$ of the energy used annually. Close to $70 \%$ of the sulphur oxides produced by fossil fuel combustion are obtained through the generation of electricity used to power our homes and offices. Some $50 \%$ of carbon dioxide emissions - mainly in industrialised countries - are a result of the operation of buildings. Regrettably, these statistics have not been taken very seriously by the construction industry and those involved in it. However, there is a growing awareness of the problem worldwide. International intervention and actions in recent years have made clear that to ensure a sustainable development, the activities of the construction sector must be controlled and managed in such a way that the natural resource base is not depleted and the environment is not degraded irrevocably. The challenge lies in ensuring sustainability without reducing the rate of construction activities or bringing some of them to a halt. The environmental problems of the construction sector in developing countries are at different levels. Material producers and builders often use traditional, less energy-efficient techniques or old-fashioned, highly polluting equipment. There is often a lack of knowledge about how to make production clean and energy efficient. Improvements might also be hindered by lack of capital or if the equipment has to be imported or lack of foreign currency. There is often weak management, both in materials production and on construction sites. In many countries energy use, and consequently air pollution, due to heating and/or cooling of buildings is very high. To some extent this is unavoidable, since the indoor climate would otherwise become unbearable, but the energy use could be much lower if buildings were better adapted to the outdoor climate. Architects and engineers are often not aware of new building design techniques that require less operational energy.

\section{Prefabricated applications, components, manufacture, and structure erection}

Sophisticated design and innovative construction techniques are becoming a common practice to minimise project 
costs while maintaining or improving project quality, durability, and operability. Use of prefabricated concrete construction can result in lower costs by a more effective material usage and reduced onsite labour. New designs are likely to combine prefabricating with cast-in-place concrete to provide composite action or to develop continuity.

1) Definition. Prefabricated is concrete that has been cast into the desired shape prior to placement in a structure. Prefabricated components can be designed and used to serve dual functions: forms for cast-in-place concrete and as a durable exterior finish. Prefabricated construction involves concrete forming, placing, finishing, and curing operations away from the project site and then erecting the prefabricated components as part of a completed structure.

2) Advantages. There are several advantages with the prefabricated construction. Prefabricating operations generally follow an industrial production procedure that takes place at a central prefabricated plant. Thus high concrete quality can be reliably obtained under the more controlled production environment. Since standard shapes are commonly produced in prefabricating concrete, the repetitive use of formwork permits a speedy production of components at a lower unit cost. These forms and plant finishing procedures provide a better surface quality than it is usually obtained under field conditions. Prefabricated components may be erected much more rapidly than conventional cast-in-place components, thereby reducing onsite construction time. Prefabricated components can be designed as insitu forms for underwater construction so that the use of cofferdams may be eliminated or substantially limited. The prefabricating process is also sufficiently adaptable, thus special shapes can be produced economically.

3) Combination of methods. The combination of prefabricating conventionally reinforced flat panel members joined with second placement concrete and post-tensioning

Table 1. Features of industrial manufacturing and the parallels in building industry

\begin{tabular}{|l|l|}
\hline \multicolumn{1}{|c|}{$\begin{array}{c}\text { Features of industrial } \\
\text { manufacturing }\end{array}$} & \multicolumn{1}{|c|}{$\begin{array}{c}\text { Requirements of industrial } \\
\text { building }\end{array}$} \\
\hline Centralised manufacturing & $\begin{array}{l}\text { Prefabrication of building } \\
\text { components in factories }\end{array}$ \\
\hline $\begin{array}{l}\text { Mass production / } \\
\text { increased flexibility of } \\
\text { production }\end{array}$ & $\begin{array}{l}\text { Development of variable standard } \\
\text { components }\end{array}$ \\
\hline $\begin{array}{l}\text { Manufacturing based on } \\
\text { standard solutions and } \\
\text { production of variants }\end{array}$ & $\begin{array}{l}\text { Standardisation of building } \\
\text { elements with flexibility in the } \\
\text { design }\end{array}$ \\
\hline $\begin{array}{l}\text { Specialisation } \\
\text { Concentration towards certain } \\
\text { segments of the market }\end{array}$ \\
\hline $\begin{array}{l}\text { Integration of planning, } \\
\text { manufacturing and }\end{array}$ & $\begin{array}{l}\text { Interaction of planning, design, } \\
\text { production, and production } \\
\text { processes as well as marketing }\end{array}$ \\
\hline $\begin{array}{l}\text { Optimised processes and } \\
\text { organisations }\end{array}$ & $\begin{array}{l}\text { Optimisation of planning and } \\
\text { production processes by } \\
\text { considering automation and } \\
\text { mechanisation }\end{array}$ \\
\hline
\end{tabular}

has proved economically advantageous for several projects. For example, this type of prefabricated construction has been successfully used for refacing lock walls, tanker gate pier construction, and guide wall construction.

4) Previous successes. The so-called "in-the-wet" or "offsite prefabrication" construction is an extension of marine construction methods that have been successfully used. This innovative method utilises prefabricated modules as the in situ form into which tremie concrete or other infill material is placed directly without a cofferdam. The pre-fabricated elements may contain all or much of the primary reinforcement. The tremie concrete is designed to work in composite action with the prefabricated modules. $\mathrm{Nu}-$ merous investigations have been conducted and designs considered by several constituencies to evaluate the feasibility of the in-the-wet method on various potential sites. These studies have shown that the "offsite prefabrication" method can provide substantial benefits in cost, construction schedule, risk reduction, facility utilisation, river traffic alleviation, and environmental impact.

5) Special requirements. Prefabricated construction has its special requirements. First of all, additional engineering effort is generally required to detail prefabricated components, to develop construction sequences, special construction tolerances, and specifications, and to optimise the design. Secondly, special labour crews and equipment may be needed to erect the prefabricated units. Where underwater erection and joining the prefabricated assemblies are involved, special efforts and techniques are required for positioning, installation, tolerance control, inspection, and quality control. Table 1 shows the features of industrial manufacturing and the parallels in the building industry.

\subsection{Prefabricated components: manufacture and classification}

1) Components. All prefabricated components are fabricated offsite as modules and erected onsite to become part of a completed structure. Individual prefabricated members may be prestressed or conventionally reinforced. The manufacture of prefabricated primarily involves the following steps:

(a) the assembly and installation of reinforcing and prestressing steel,

(b) the production and placement of concrete and the subsequent curing, and

(c) the lifting, storage, and loading-out of the completed component. Prefabricated production is basically an industrial manufacture process. It is appropriate to require more rigorous control on cleanliness, temperature, and moisture of the aggregates and on accuracy of batching and mixing time, and on tolerance.

2) Manufacture. (a) Prefabrication normally requires more thorough curing than conventional cast-in-place con- 
crete, because prefabricated sections are generally thinner and more highly stressed during handling, transportation, and erection. Therefore, an adequate means of curing must be specified and enforced. Steam curing at atmospheric pressure is widely employed in prefabricated manufacture to accelerate the early-strength gain and permit daily turnover of forms. The adoptions of a proper cycle of steam curing and subsequent water curing are essential for good quality prefabricated. When prefabricated products are removed from steam curing, the moisture extraction from the concrete is accelerated due to the change in temperature and humidity, so the products must be covered for protection from wind and rapid changes in temperature and moisture.

(b) External vibration is useful in eliminating surface defects but generally cannot extend its effects more than $15-20 \mathrm{~cm}$ into concrete. For thicker concrete panels external vibration is not effective to consolidate the inner portion of the concrete. Internal vibration is required for an adequate consolidation of concrete.

3) Classification. In terms of their functionality and structural characteristics prefabricated components used in hydraulic structures can generally be classified into two categories: prefabricated panels and prefabricated assemblies.

(a) Panels. Prefabricated panels are the basic elements that can be used either individually as resurfacing panels or used as structural components in a large prefabricated assembly. During the construction stage individual prefabricated panels are mostly subjected to loads from lifting hoists and erection bracing.

(b) Assemblies. Precast assemblies refer to large prefabricated concrete modules for "in-the-wet" construction of hydraulic structures. These assemblies are typically boxlike structures ranging from a dozen feet to several hundred feet in length and width. They are erected on project sites, often underwater, as in-situ forms into which tremie concrete can be directly placed without use of a cofferdam. For float-in construction, the prefabricated assemblies must have bottom plates to allow flotation and contain several compartments to allow sequential ballasting. For lift-in construction the prefabricated assemblies normally do not contain any bottom plate but are fitted with a lifting frame to distribute lifting loads.

4) Prefabricated similar components. In prefabricated construction, substantial economy can be achieved through repetition of prefabricated numerous prefabricated components of the same or similar shape and size. Although prefabrication of prefabricated assemblies can be carried out in several ways, the most common prefabrication method is to assemble a large prefabricated module by erecting smaller pieces of prefabricated panels/shells and making closure pours at the junctions of these panels/shells. Some- times the individual panels are pretensioned and the assemblies are posttensioned to meet the strength and serviceability requirements.

\subsection{Permanent structures}

a) Prestressed members. Completed structures built of prefabricated components may be conventionally reinforced, prestressed, or both. Prestressed concrete may be constructed by either the pretensioning method or the posttensioning method. Pretensioning is the imposition of prestress by stressing the tendons against external reactions before placement of fresh concrete in the forms, then allowing the concrete to set and gain a substantial portion of strength before releasing the tendons, so that the stress is transferred into the concrete. Posttensioning is the imposition of prestress by stressing and anchoring the tendons against already hardened concrete.

b) Reinforced members. Conventionally reinforced prefabricated and prestressed concrete members and systems, whether they are cast-in-place or prefabricated systems. The nominal values for support length to be used at the initial stage of projects are illustrated in Table 2 and beam-beam connection and floor beam connections in Figs 1, 2.

Table 2. Nominal values for support length to be used at the initial stage of projects

\begin{tabular}{|l|c|c|c|c|}
\hline $\begin{array}{c}\text { Suppor- } \\
\text { ting } \\
\text { structure }\end{array}$ & $\begin{array}{c}\text { Hollow } \\
\text { core units } \\
120 \mathrm{~mm} \\
400 \mathrm{~mm}\end{array}$ & $\begin{array}{c}\text { Ribbed } \\
\text { soffit units: } \\
\text { low - heavy } \\
\text { loading }\end{array}$ & $\begin{array}{c}\text { Floor } \\
\text { plates }\end{array}$ & $\begin{array}{c}\text { Beam- } \\
\text { block floors }\end{array}$ \\
\hline $\begin{array}{l}\text { Reinforced } \\
\text { concrete or } \\
\text { steel } \\
\text { girders }\end{array}$ & $70-130$ & $75-150$ & 70 & 100 \\
\hline $\begin{array}{l}\text { Brick } \\
\text { masonry }\end{array}$ & $100-150$ & & 100 & 125 \\
\hline
\end{tabular}

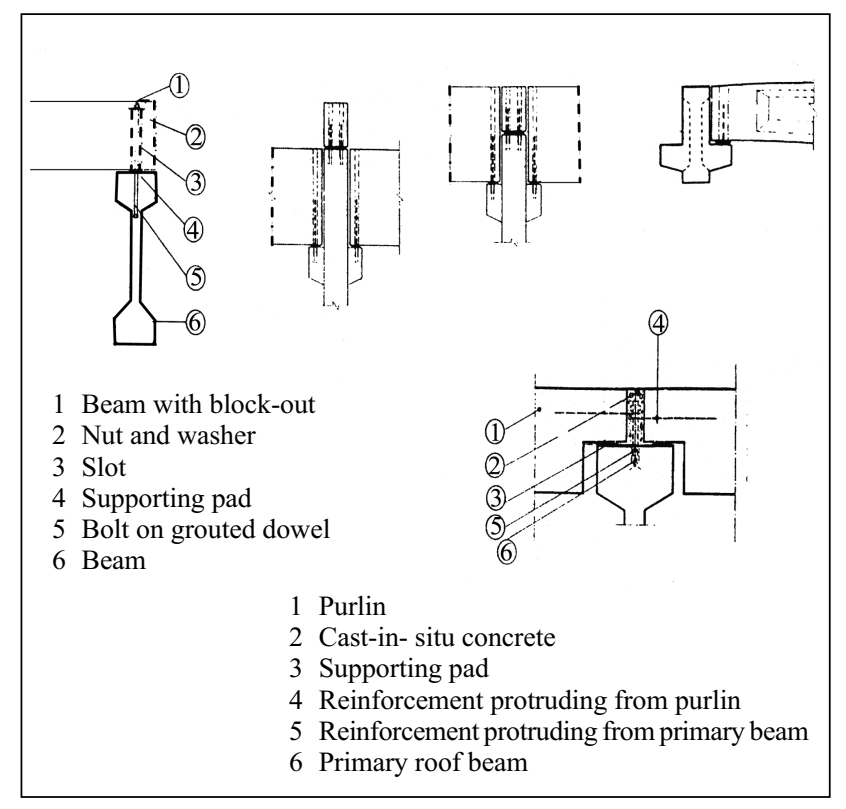

Fig 1. Beam-to-beam connections 


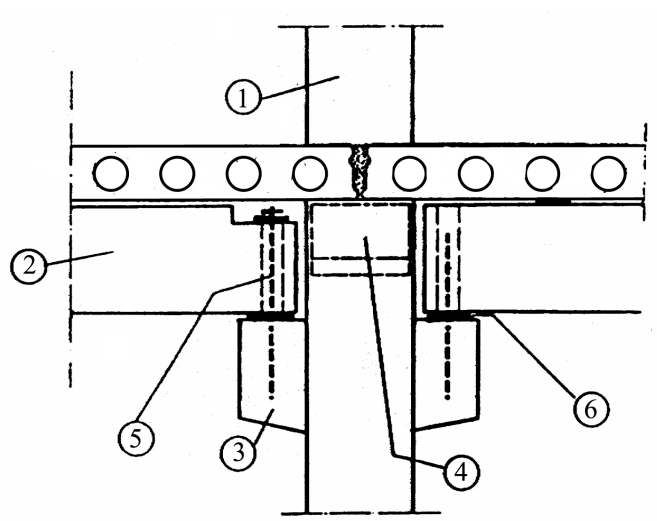

1 Column

2 Floor beam

3 Corbel

4 Additional corbel for floor support for columns larger than $400 \mathrm{~mm}$

5 Bolt or grouted dowel

6 Supporting pad

Fig 2. Example of beam-to-column-to-floor connection

\section{Evaluation of design method}

The objective of this paper is to use the practical development of prefabricated construction system through an analysis of industrialised building methods efficiently with the application of knowledge, employment ideas and responsibility, to give new impulses for the development of future industrialised building. It concerns an economically optimal structural system of prefabricated construction system units. With consideration to create the necessity of places it is to be designed for; limited financial means, the rapidly growing total population which is of enormous importance in a simple system, and ease of adaptability as well as use in order to meet the construction demands. System functioning is shown on the basis of an example, with which the variability of the system makes it possible to adapt the building to necessitate changes in the space offered and to the rising numbers of occupants/people. As an example, one begins with a small school which possesses only the most necessary areas, which can be extended; like the construction or addition of areas for different functions. An

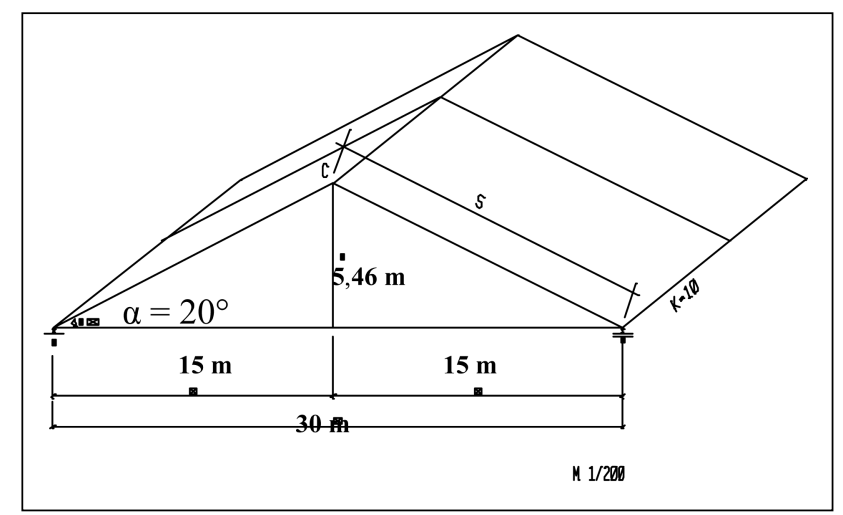

Fig 3. Principal sketch and dimensions economical optimisation is to be achieved with establishing the building efficiency, speed, short construction period, economy and flexibility. The author has developed an evaluation of this design method for a prefabricated concrete saddle roof from a prefabricated construction element as round steel bar. This approach deals with the systems concept of building structures, efficiency and cost-benefit considerations as well as dimensional coordination and control. Emphasis is placed on planning, design, manufacturing and construction of prefabricated and prefabricated concrete structures, their cost advantage with respect to insitu concrete, and techniques for jointing, and integration of horizontal and vertical members. The principal sketch and dimensions are illustrated in Fig 3; Eq 1 shows the solution of method, Fig 4 shows an onsite assembly of a school building.

Equation 1 shows the solution of the method.

a) 1 (length) $=30,00 \mathrm{~m}, h$ (height) $=5,46 \mathrm{~m}, S$ (long) $=$ $15,96 \mathrm{~m}$, and $\alpha=20^{\circ}$.

b) Load:

1) Dead weight binder: selected $60 / 100$ [cm] and $\rho_{\text {concrete }}=2,400 \mathrm{~kg} / \mathrm{m}^{3}$;

$2,400 \mathrm{~kg} / \mathrm{m}^{3} \cdot 0,6 \mathrm{~m} \cdot 15,96 \mathrm{~m}=1,440 \mathrm{~kg} / \mathrm{m}=$ $14,400 \mathrm{KN} / \mathrm{m}=g_{1}$.

2) Roof membrane and roof slabs: estimated also, $1,0 \mathrm{KN} / \mathrm{m}^{2}$;

$K=10,00 \mathrm{~m}, g_{2}=10 \mathrm{KN} / \mathrm{m}$,

3) Pay load: wind ( $w$ ): pressure $=w_{1} 0,8 \mathrm{KN} / \mathrm{m}^{2}$

Drag force $=w_{2}=0,4 \mathrm{KN} / \mathrm{m}^{2}$.

c) System and load:

$g=g_{1}+g_{2}=14,4+10,0=24,4 \mathrm{KN} / \mathrm{m}, g_{V}=g / \cos ^{2} \alpha=$ $24,4 / \cos ^{2} 20=27,63 \mathrm{KN} / \mathrm{m}$.

$W_{2 V}=W_{2} \cdot \cos \alpha=3,76 \mathrm{kN} / \mathrm{m}, W_{2 H}=W_{2} \cdot \sin \alpha=$ $1,37 \mathrm{KN} / \mathrm{m}$.

$W_{1 V}=W_{1} \cdot \cos \alpha=7,52 \mathrm{kN} / \mathrm{m}, W_{1 H}=W_{1} \cdot \sin \alpha=$ $2,74 \mathrm{KN} / \mathrm{m}$.

d) Static calculation:

1) Support: $\Sigma M_{A}=0:-g_{V} \cdot 1 \cdot 1 / 2-W_{1 H} \cdot h^{2} / 2-W_{1 V}$. $1^{2} / 8\left((1 / 2)^{2} / 2\right)-W_{2 H} \cdot h^{2} / 2+W_{2 V} \cdot 1 / 2 \cdot(1 / 2+1 / 4)+\mathrm{B} \cdot 1=0$ $\Rightarrow \mathrm{B}=402,39 \mathrm{KN}$

$\Sigma V=0: A_{V}+B-g_{V} \cdot 1-W_{1 V} \cdot 1 / 2+W_{2 V} \cdot 1 / 2=0$

$\Rightarrow A_{V}=482,91 \mathrm{KN}$

Control: $\Sigma M_{B}=0: A_{V} \cdot 1-g_{V} \cdot 1^{2} / 2+W_{1 H} \cdot h^{2} / 2-W_{1 V}$.

$1 / 2 \cdot W_{1 H} \cdot h^{2} / 2-W_{1 V}$.

$(1 / 2+1 / 4)+W_{2 V} \cdot 1^{2 / 8}+W_{2 H} \cdot h^{2} / 2=0 ; 0=0 \mathrm{OK}$

$\Sigma H=0: W_{1 H} \cdot 5,46+W_{2 H} \cdot 5,46-A_{H}=0, A_{H}=22,44 \mathrm{KN}$

2) Tension power in member $3: \Sigma M_{C}=0:\left(g_{V} W_{2 V}\right)$. $(1 / 2)^{2} / 2-W_{2 H} \cdot \mathrm{h}^{2} / 2-\mathrm{B}$.

$1 / 2+Z \cdot 1=0, Z=617,38 \mathrm{kN}$

3) Moments: (max $M$ left from $C)$.

Control: $\Sigma Q(x)=0, \mathrm{Z} \cdot \sin \alpha-A_{V} \cdot \cos \alpha-A_{H} \cdot \sin \alpha+$ $W_{1 H} \cdot x \tan \alpha \cdot \sin \alpha+\left(g_{V}+W_{1 V}\right) X \cdot \cos \alpha=0,-250,306+$ $33,371 \mathrm{x}=0 \Rightarrow x=7,50 \mathrm{~m}$, 


$$
\begin{aligned}
& M \max =\mathrm{M}(x=7,50 \mathrm{~m}) \\
& M(x)-A_{V} x+\left(\mathrm{Z}-A_{H}\right) x \tan \alpha+W_{1 H}(\mathrm{x} \cdot \tan \alpha)^{2} / 2+ \\
& \left(g_{V}+W_{1 V}\right) . \\
& \sigma_{\mathrm{Zul}, \mathrm{St} . \cdots}=14,5 \frac{\mathrm{kN}}{\mathrm{cm}}=\mathrm{St} \cdots 37 \mathrm{~S} \\
& \sigma=\frac{\mathrm{N}}{\mathrm{A}} \cdots \operatorname{mit} \cdots \mathrm{N} \approx 618 \mathrm{kN} \\
& \sigma \cdot \mathrm{A}=\mathrm{N} \Rightarrow \mathrm{A}=\frac{\mathrm{N}}{\sigma}=\frac{618}{14,5}=42,62 \mathrm{~cm}^{2} \\
& \mathrm{~A}=\mathrm{d}^{2} \pi^{2} \pi \\
& \Rightarrow \mathrm{d}=8 \mathrm{~cm} \cdots(\mathrm{r}=4 \mathrm{~cm}) \cdots \mathrm{steel} . . \mathrm{bar} . \\
& X^{2} / 2=0, M \max =M(x)=998,969 \mathrm{KNm} \\
& 4) Q \max \text { und } N \max \text { in } A: Q \max =Q_{\mathrm{A}}=A_{V}-\cos \alpha- \\
& A_{H} \cdot \sin \alpha=446,11 \mathrm{kN} \\
& N \max =N_{A}=-A_{V} \cdot \sin \alpha-A_{H} \cdot \cos \alpha=-186,25 \mathrm{KN} .
\end{aligned}
$$

\section{Erection of prefabricated concrete members in underwater applications}

For the "in-the-wet" construction, erection of prefabricated modules can be carried out by either float-in method or lift-in method or a combination of both. Anchorage of longitudinal tie bars to hollow core units is illustrated in Fig 5.

1) Float-in method. The float-in construction method entails transportation of prefabricated large concrete modules from their casting yard or outfitting site to the project site through floatation and/or by means of external buoyancy tanks. Once the float-in modules are precisely positioned over the site with a suitable mooring system, guide piles, or taut lines and winches, they are lowered down to the prepared foundation by means of ballasting. Float-in prefabricated modules usually take the form of floating structures with many compartments for sequential ballasting.

2) Lift-in method. Lift-in construction entails transportation of prefabricated prefabricated modules from their

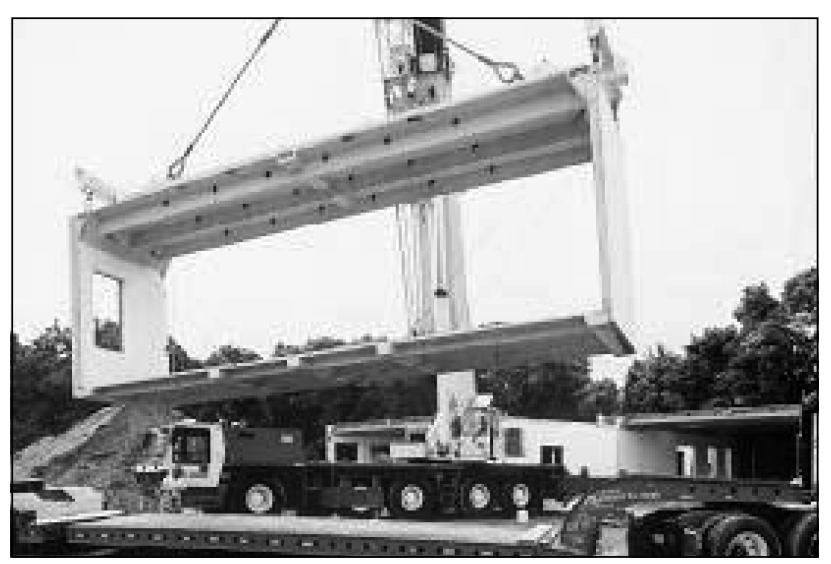

Fig 4. On-site assembly of prefabricated panels casting or outfitting yard to project sites by towed barges or floating cranes. The lift-in concrete modules themselves do not float. Heavy lift equipment must be used to control position of the modules while lowering them down to the river bottom to acceptable erection tolerances. Auxiliary guiding systems, such as mooring systems, tensioned guidelines, and guide horns, are often used to assist the positioning. Installation of lift-in prefabricated segments is largely independent of water level but is somewhat constrained by river flow velocity, with a normal upper limit of $2 \mathrm{~m}$ per second on basis of prior experience. However, units have been installed in a current up to $3 \mathrm{~m}$ per second where special procedures have been implemented.

3) Selection of method. Selecting the erection method for the pre-fabricated modules is an important design decision. Each erection method has its special implications to project cost, construction schedules, river traffic, towing and mooring system, positioning accuracy, and level of risks during construction. In many ways the erection method will at least in part determine the size and configuration of the prefabricated modules, the foundation treatment, construction sequence, and schedule. In general, a thorough evaluation should be made in the early stage of design to determine the effects of the erection methods, because the erection method and equipment to install prefabricated modules will affect the structural concept and layout, fabrication of prefabricated components, and construction logistics.

4) Effects on cost and schedule. The number of prefabricated modules and underwater joints between these components has significant effects on the construction cost and schedule. Underwater joining of prefabricated components is costly and difficult to perform, and the installation of numerous small prefabricated modules also has adverse implications to the cost and quality control. In principle, use of large prefabricated modules usually provides considerable benefits in cost saving, project schedule, and construction quality control. However, the size of the prefabricated modules is primarily limited by a number of factors such as the draft requirements and the lift capacity of crane barges that are available or economically obtainable.

5) Positioning the module. a) For in-the-wet construction, accurately positioning the prefabricated modules underwater is one of the critical operations. Underwater positioning of the prefabricated modules requires an intensive onsite coordination of several operations, including surveying, sequential ballasting and/or lift crane maneuvering, operations of guiding devices and hydraulic rams, positioning control with flat jacks, taut lines, and winches, and inspection by divers;

b) Surveys carried out during the erection shall require a high degree of accuracy for vertical and horizontal alignments of the prefabricated modules. Engineering specifi- 


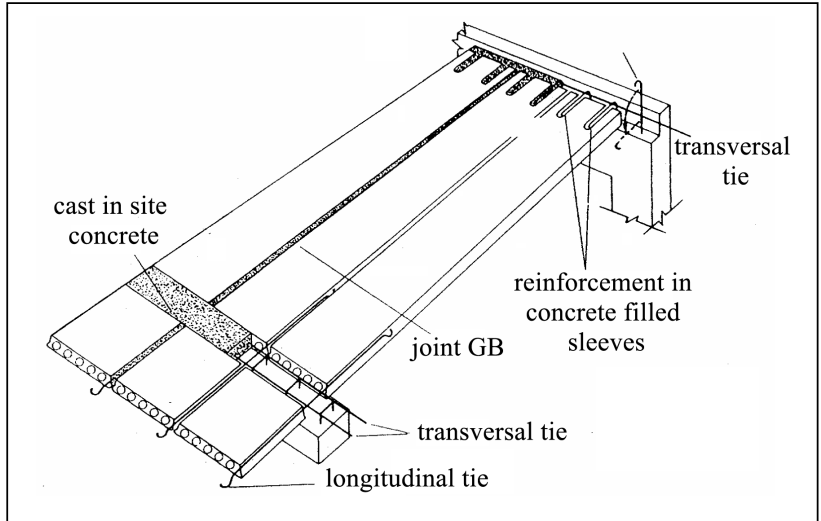

Fig 5. Anchorage of longitudinal tie bars to hollow-core units

cations require multiple survey systems such as DGPS, lasers, and underwater sonic sensors. It is more reliable and expedient for the operators to rely on spotting and controlling targets above water than on underwater instrumentation. Therefore the land-based survey method and GPS should be the primary systems for monitoring the placement, while the use of underwater sonic devices and divers are supplementary methods that cross-check the other survey readings.

\section{Industrial manufacturing methods for reinforced concrete and reinforced lightweight concrete}

The material-specific problems of industrial manufacturing methods are presented in the following groups of materials: reinforced concrete, steel, wood and wood group materials in comparison. With the comparison of shaping characteristics, the plastics are also included for completing the material-specific problem. The industrial manufacturing methods used in material prefabrication differ with the kind of shaping by different materials:

Prototype direct shaping from the unreformed basic material by pouring, sintering, pressing together, partly by addition of bonding agents and aggregates:

- with metals in the melted condition;

- with thermoplastics in the thermoplastic condition;

- with hardened thermosetting polymers in the unhardened condition;

- with sinterable, mineral materials such as loam, clay/ tone in not-burned condition;

- with hardening, mineral materials such as gypsum heavy and lightweight concrete in the unhardened condition;

- with timber materials such as splinter and fibre boards from the fibre bonding agent mixture. Transforming shape by warm and cold shaping from a preformed semi-finished material;

- with metals by rollers and extrusion of strand-poured before products;

- within the warm form range, by deep-drawing and roll bend from rolled-sheet metals within the cold form range shaping by adding individual parts;

- with metals by fusing such as welding and soldering;

- with all materials by sticking and bolting, furthermore adding by means of more numerous not solvable and solvable connecting devices.

In the industrial system the materials used to erect a building due to very different material parameters for course and pressure strength, flexible forming capacity, flow behaviour etc also have very different transforming behaviour. Metals make numerous shaping procedures possible within a large transforming range with large transforming forces. Thermoplastics make possible numerous reforming procedures with relatively small transformation forces of adjoining timber materials and can be only very conditionally transformed. Thermosetting polymer plastics and mineral materials cannot be stressed and transformed.

\subsection{General views}

It is important to make clear that industrialised building does not automatically imply an increased productivity, reduction of person-hours, or a better economy. However, it does offer this possibility if a pragmatic totality concept is applied. Likewise, production indoors can also be craftbased (or manual) which implies that it is not the location that is decisive, but the conditions that are important - the benefit in this case is that the workers have a roof over their heads. There is a broad spectrum of techniques available for industrialised building. It is impossible to mention all simply because the techniques are steadily under development with new ones being invented in addition to opinions differing on whether a technique is or is not 'industrial'. In any case, techniques mentioned in connection with industrial building include the following methods:

1. Standardisation (eg components, methods, processes or dimensional standardisation and modularisation);

2. Prefabrication (manufacturing components beforehand, similar to off-site fabrication);

3. On-site fabrication (manufacturing components on site or in a field factory);

4. Preassembly (materials, prefabricated components and/or equipment are joined together for subsequent installation);

5. Modular buildings (units enclosing a usable space and forming a part of the building structure);

6. The building system (a product system with an organised entity consisting of components with defined relationships, including design rules);

7. Mechanisation (the use of mechanical equipment instead of manual labour); and automation (utilisation of programmable machines, eg robots performing tasks, or of computerised tools for planning, design and operation). 
Most associate industrialised concrete building with prefabricated concrete. It was during the mass production era, in the 1950s, 60s and 70s that the first steps towards a more industrialised construction started. Prefabrication is not a novel concept; famous buildings in the ancient world (Egypt, Greece, and Italy) were erected with prefabricated components made of stone. However, industrialised building does not necessarily equate with mass production; industrialisation can be achieved in projects by adopting system-based solutions. Such solutions should include a concept of structural elements which may be project specific in addition to having standard interfaces so that they can be assembled in a simple and standard manner. Furthermore, it should also include a predefined manufacturing and construction process with the delivery of components at an exact time they are required. Prefabrication is appealing because it reduces on-site activities and thus eliminates some of the construction peculiarities (eg work performed in sub-optimal conditions). The concept of prefabrication as a production system is good; however, it does have various implications for the process. It is worth mentioning that the total process tends to be more complex and requirements for co-operation and co-ordination within the design are higher and the error correction cycle is longer [1]. One of the implications is that there is a need or requirement to have a quality control system for all activities during the whole process in order to eliminate defects and mistakes (or mainly to reduce the variation; 'zero defects' are virtually impossible to achieve). De facto quality control is needed whatever production system or method is used. However, for prefabricated systems and components this is of particular importance since the requirements on dimensional tolerances are more severe. According to [2], the main problem of prefabrication today is the lack of a system approach to its employment among the diverse parties involved.

\subsection{Prefabricated brickwork}

Currently very little use is made of prefabricated brickwork and the vast majority of brickwork is constructed by traditional skills employed directly on the building or engineering site. This aspect of the procurement of brickwork has not changed over many decades. Whilst many brick manufacturers and merchants do supply special brick units to be made into small pre-assembled building components, such as minor brickwork arch sets, any recent attempt has been made to produce and supply larger prefabricated brickwork elements on a consistent and regular basis. Prefabrication does hold out the opportunity for significant improvements in overall building construction efficiency, quality and greater economy over traditional site constructed work.
At the same time it is important to maintain the basic characteristics and attributes of brickwork as a construction material including attractive appearance, longevity, low ongoing maintenance and sustainability.

\section{Conclusion}

The precast and prefabricated construction system mentioned in this research can be used in developing and other countries to give a new impulse for the development of building. It concerns an economically optimal structural system of prefabricated units. Climate, political and economical influences were also considered in this work. System functioning is shown on the basis of an example, with which the variability of the system makes it possible to adapt with the necessary changes in the floor area offered due to the rising numbers of students. For instance, if we are to begin with a small school that possesses only the most necessary areas and classrooms, it has the possibility to be extended for the construction of additional requirements such as: a sports resource centre (ie gymnasium), libraries and other areas for different functions. Economical optimisation is a function of the construction period, construction cost, performance and versatility of use of the building. Construction of prefabricated concrete structures is less costly compared to in-situ concrete due to the repeated use of auxiliary equipments and shuttering; most importantly the overhead cost is significantly less.

In the literature, all scientific fields were worked out based on the efficiencies, costs, benefits, choice of execution design, technical demands, aesthetical point of view, as well as on the total economics. In the current example of a school building, the following criteria were regarded: the optimal superstructure of prefabricated concrete building systems; the particularity of developing countries (eg the climate, the political and the economic conditions); the time for construction and necessary innovative developments for an economically optimised superstructure.

\section{References}

1. KOSKELA, L. An exploration towards a production theory and its application to construction. VTT Netherlands on 23/ 24 April 2002. Publications 408. Technical Research Centre of Finland, Espoo, 2000.

2. WARSZAWSKI, A. Industrialised and automated building systems - a managerial approach. E \& FN Spon, London, 1999. 


\section{SURENKAMŲJŲ PASTATŲ KONSTRUKCIJŲ OPTIMIZAVIMAS VALDYMO IR EKONOMINIU POŽIŪRIAIS}

\section{A. Abdallah}

\section{Santrauka}

Aprašomi naujausi tyrimai, mokslinès naujovès sprendžiant surenkamujų pastatų sistemų valdymo ir ekonominès optimizacijos klausimus. Apžvelgta literatūra, kurioje nagrinèjami efektyvumo, sąnaudų, pelno, statybos projektavimo, techninių reikalavimų, estetiniai, ekonominiai klausimai. Pateikiamas pavyzdys - mokyklos pastatas, skirtas besivystančių šalių bendruomenėms. Šiuo pavyzdžiu vertinami tokie rodikliai: gelžbetoninio surenkamojo pastato antžeminès dalies optimalumas, besivystančių šlių specifika (pvz., klimatas, politinės ir ekonominès sąlygos), statybos laikas ir reikalingi patobulinimai ekonomiškai optimaliai antžeminei daliai pastatyti. Be to, reikalingi alternatyvūs statybos metodai, taip pat turi būti kuriamos lanksčios, lengvai pritaikomos kintantiems poreikiams konstrukcinès sistemos.

Reikšminiai žodžiai: statybos valdymas, ekonomika, surenkamosios sistemos, valdymo ir ekonominis optimizavimas.

Ahmed ABDALLAH. Doctor, Dissertation Supervisor for British Columbia Institute of Technology (BCIT) Canada, Construction Management Program in conjunction with the University of Bath, UK.

Master of Science (1996) in Civil Engineering, Dept of Construction Management and Engineering Economics, Technical University of Vienna, Austria. Doctor of Science (1999) Technical University of Vienna, Austria.

Postdoctoral fellow 2000 at the University of Western Ontario, London, Ontario, Canada, Dept of Civil and Environmental Engineering, Research Associate, research on rock mass grading, tunnelling techniques, prefabricated concrete etc. Author of multitudinal articles and presentation at several international conferences. Member of the American Society of Civil Engineers and reviewer their Journal. Research interests include the areas of analysis, investigation design and management of buried infrastructure systems. Other research problems: productivity, risk assessment, reduction of overall life-cycle costs, project management, organisation, selection and purchase recommendations of earthmoving equipment, ground behaviour, scheduling, cost estimation and control, planning and resource management, cost and value analysis, commercial procurement and strategic management. 